\title{
A Review of the Implementation of Quality Function Deployment in Various Service Areas
}

\author{
Ms. Vaishnavi R. Holey \\ PG Student, Mechanical Engineering, Government College of Engineering, Amrawati \\ Received on: 08 April, 2021, Revised on: 01May, 2021, Published on: 04 May, 2021
}

\begin{abstract}
Quality Function Deployment (QFD) is a define as a quality tool or product or service that helps to convert the voice of customer $(\mathrm{VoC})$ to the new product or service that truly satisfied the customer's needs. It will be reviewed in order to understand how it works and highlight its strengths and weaknesses and to discuss its practical applications. It will be defined and explained by means of an example and a number of benefits and implementation problems will be revealed. It helps to understand the importance that customers what exactly want or to attach their various expectations. It is a challenge to understand what the customers exactly want. It's an approach of multi-functional- various stakeholders in the design process come together from the project's inception to concurrently plan, design and produce a service. In this paper the various areas of $Q F D$ are studied and this paper provides the general overview of QFD methodology and approach to product or service development and hence promotes QFD future development.
\end{abstract}

Keywords - Quality Function Deployment, Voice of Customers, House of Quality

\section{I- INTRODUCTION}

$\mathbf{I}_{\mathrm{n}}$ recent trend today it is essential for companies to continually know about the changing expectations of its customers. Quality function deployment (QFD) is the powerful process to know the customer requirements and design or to developed new services. It is also useful to modify the features and designs of its existing service or product according to the changed requirements of the customers. QFD helps to understand the importance that customers problems and their various expectations belong to their service. It is a challenge to understand what the customers exactly want.

In order to build a quality of service of customers ${ }^{\text {ee }}$ requirements (CR) have to be considered and addressed. From the view of designer the customer needs could seem to be qualitative, incomplete and sometimes inconsistent. Customers only express what they want. Most likely questions that what's do not imply any "what exactly" in terms that make sense to easy to use. Designers need to figure out how these does can be satisfied customer by a service. Designers need detailed of customer requirements (how's) for design.

There is obvious gap between what's and how's. The Customers "what's" are usually expressed in customers ${ }^{\text {ee }}$ own language without any implication of implementations. The customer what's exactly need to be translated into designer's how which quantitative, measurable is, and actionable technical specifications are so that they can be used by designers for service design. Quality Function Deployment (QFD) is one of the 


\section{International Journal of Innovations in Engineering and Science, www.ijies.net}

important techniques that can build the gap between the customer and service and it help to translate customers what's to be design.

\subsection{When to use QFD:}

It is applied in the early stages of the design phase so that the customer exactly wants are incorporated into the final service. As well as it can be used as a planning tool as it identifies the most important areas in which the effort should focus in relation to our service capabilities.

Ask yourself these questions:

1. Why do QFD in this case?

2. What will the QFD are made of?

3. Is it the right service at this time?

4. Is this the right place for implementation?

5 . What is the goal of service and what is success?

6. Who all should we involve?

\subsection{How to use it?}

Comprehensive QFD may provide four phases:

1. Service Planning (House of Quality): Translate customer requirement into service requirement into the service required to meet them.

2. Service Design: Translate technical requirement to key part systems.

3. Process Design: Identify key process operations necessary to achieve key part characteristics.

4. Process Control: Establish process control plans, maintenance plans, training plans to control operations.

To follow these steps to establish what exactly wants or needed the customer in their respective service.

Follow these steps:

1. Learn what each element represents

2. Form a multidisciplinary team. Obtain voice of the customer from customer surveys, observations, interviews. To identify customer basic requirements and ask customer to rate of importance.

3. To development the first issue of the charts is that the most time consuming part. Conduct competitive analysis by customer requirement establish a quality plan based on competitive for future service.

After completed regular reviews and updates required minimum time. Benefits of Quality Function Deployment include better understanding of customer demands and design interaction and early planning and involvement during the design process reducing iterations and focusing the customer service while conducting the successful teamwork.

\section{II- QUALITY FUNCTION DEPLOYMENT METHODOLOGIES}

A Quality Function Deployment tool (QFD) uses a matrix process to collect topics that are essential to the planning process. The House of Quality Matrix is widely used form of this method. Quality Function Deployment is a method to use for translating voice of customer and their requirements into functional design of service. Following are the four major characteristics of QFD as a quality system. First of all the quality function deployment is a quality system that merge the elements of system thinking for example to viewing the development process as a system, and the psychology or being able to conceptualize customer concerns, what value is being determined, and how customers or end users become interested, choose, and are finally satisfied. Secondly QFD is a quality method of good service. This addresses how the needs of the customer are determined, which features are to be incorporated, and what level or degree of performance is to be determined. Thirdly, QFD is a strategy for competiveness. It maximizes positive quality that adds good worth. QFD brings outspoken and unspoken customer needs and translates them into technical functions. Finally, Quality Function Deployment is the only Comprehensive quality system targeted specifically at satisfying the customer through the development and business process as from beginning to end. Following are the steps to implementation of quality function deployment (QFD).

- Develop a list of customer requirement,

- Developed a list of technical design elements along the roof of the house i.e. House of matrix,

- To construct the relationships between the 


\section{International Journal of Innovations in Engineering and Science, www.ijies.net}

customer requirements and design elements,

- Identify the co-relations between design elements in the roof of the house,

- To Perform a competitive assessment of the customer requirement,

- Prioritize customer requirement,

- Prioritize technical requirement, and

- Final evaluation

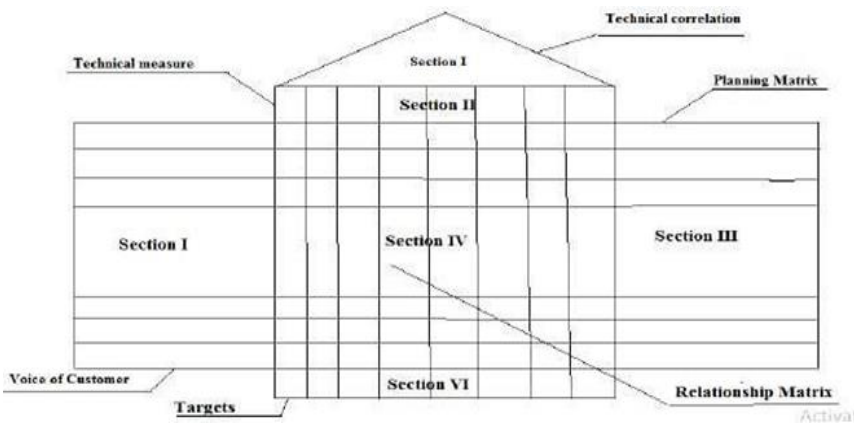

Fig 1- General House of Quality Structure

- Section I- Customer needs and requirements (voice of customer, VOC)

- $\quad$ Section II- Technical measures

- $\quad$ Section III-Planning matrix

- $\quad$ Section IV-Relationship matrix

- Section V-Correlation matrix

- $\quad$ Section VI-Weights and benchmarks and targets Standard structure for the House Quality (HoQ) is shown in Fig.1 above.

This tool takes customer preferences and demands and then translates them into technical requirements that can be quantified, measured, and analyzed. After analyze the results can then be used to determine the focus of experiments and research. It can be divided into eight different sections. The various sections (or rooms) are sometimes referred to as the "What" is an Importance and Customer Competitive Assessment and "How" Relationship is Absolute and Relative Score, Correlation Matrix, Technical Competitive Assessment and Target Value "rooms" (section). The "What" room is the section that houses customer requirements as seen on fig.2.1. The Importance Ratings and Customer Competitive Assessment contains information grouped for analysis, and is located on the right area of Figure1 labeled as Planning Matrix or Customer Perceptions. The "How" room is the area that lists the measurements that will be used for each "What" and is labeled Technical or Design Requirements at the top of Figure1. The "Relationship Matrix" room or Interrelationship Matrix area of the HoQ explores all of the interactions between the various "what's" and "how's". The absolute and relative Score rooms also known as the "Prioritized Requirements" area is at the bottom of the HoQ and where the total scores for each "how" are evaluated based on several factors. The next area known as the "Correlation Matrix" is where the relationships between the various "how's" and technical requirements are evaluated. Some of this benefit each other or stand in direct contradiction and knowledge of these interactions aids the design process in optimizing the various requirements. The Technical Competitive Assessment is also known as the Competitive Benchmarks near the bottom of the House of Quality which evaluates how the product compares to similar competing products. The final area is the Target Values or the Technical Targets area at the bottom of the HoQ, which lists the recommended specifications for the given product.

\section{III- LITERATURE REVIEW}

\subsection{Introduction}

This review is based on the work done in Quality Function Deployment in various sources. The literatures show the work done in the field of design the House of Quality and analysis of the ideal model. The objective of this review is to identify the contribution of the researcher in the designing and analysis of the HoQ method and work done on the QFD.

Ravi Kumar Singh, Virendra Rajput, and Amit Sahay [1] this paper deals with the applicability of Quality Function Deployment (QFD) to shift Customer expectations in to design quality. For this purpose, customer needs and service requirements are determined through direct interviews, observation and data analyses. The quality and prioritization of customer needs are done on the hierarchy diagram providing accurate ratio-scale priorities. Following the categorization and prioritization of customer needs and the requirements were then converted into quality characteristics. Quality characteristics thus identified are converted in the product design specifications using Quality function deployment (QFD).In this study, QFD methodology, which is used in several industries, is implemented in the Automobile industry. The relationship, which is between service and customer's requirements, is 


\section{International Journal of Innovations in Engineering and Science, www.ijies.net}

determined. After the all steps follow the customer requirements and technical details are put in the house of quality (HoQ). The House of Quality Matrix build for the phases product planning, product Design and Process Characteristics respectively, shows the relationship between the various elements and gives a direction to the organization where it can do improvement in the service or product Quality and in the product or service design.

Dr. Chandu Ravi Kumar \& Dr. Ch. Venkata Krishna Reddy [2] this paper have reviewed that the transport industry or sector is one of the service sectors which contributed much to the economy of the country and also plays important role of reducing unemployment. A basic function of public transport industry should be well organized around to satisfy the customers or passenger. When the passengers are satisfied the service then the public services is credited with proving effective service opportunities. Public or any type of transport sector should become part of a solution for sustainable transport in the future. Aim of this paper is to increase public transport use to the service should be designed and performed in a way that accommodates the levels of Service required by customers.

Sumit N. Balwani [3] this paper is reviewed that Quality Function Deployment (QFD) was established in Japan in the late 1960's and introduced to America and Europe in 1983. Quality function deployment (QFD) is a "method to transform user demands into design quality and to deploy the functions forming quality and to deploy methods for achieving the design quality into subsystems and component parts and ultimately to specific elements of the manufacturing process. In this paper the various applications of QFD are studied and this paper will provide a general overview of the QFD methodology and approach to product development.

K.Ch.A.Rao and Girish Thakar [4] this paper reviewed that Quality must be designed in to the product, not inspected into it. In order to build a quality product, customers ${ }^{\text {ee }}$ requirements have to be considered and incorporated in to the product. It is a tool for bringing the voice of the customer into the product or service development process from conceptual design through to manufacturing. It begins with a matrix that links customer requirements (CRs) to technical requirements (TRs) along with competitive benchmarking information and further matrices can be used to ultimately link this to design of manufacturing system. Public transport system plays an important role in any city or village as thousands of people depend on it for their transportation in the city or village. Over the past few years, cities have been growing at a tremendous pace in every aspect, including the public transport services. This paper is aim to the discussion of "how to gain the passenger satisfaction" of the most popular type of public transport system namely the metropolitan or any type of bus service through Quality Function Deployment.

G. E. Barkavi, Dr. A.Mahadevan, Dr. R. Ramesh[5] This paper is reviewed that the service sector of transportation industry, customer satisfaction is primarily reliant on providing services like convenient, comfortable, luxurious and affordable facilities before, during and after the journey. Thousands of factors contribute and augment the quality of service rendered to the customer. In this paper the author has applied the Quality Function Deployment implement to control the requirements of customers specifically with high opinion to the seats provided in the public buses with special reference to the city used for long distance journey. The study in work of literature the customer requirements and develops the service quality of buses that carry passengers over long journey.

Michael D. Myers Kambiz Maani [6] this paper is reviewed that customer is to driven planning and communication process for designing, developing or improving products or services and is a particular implementation of the Total Quality Management philosophy. Its approach is multifunctional-various stakeholders in the design process came together from the project's inception to concurrently plan, design and produce a product or service. Some particular case the company has not only applied the principles of QFD to manufacturing processes and its approach has also been applied to other areas of the business including information systems development. This paper discusses how the various applications of a QFD approach to information systems development have changed the relationship between the users and the process of systems development by itself.

\section{IV- IMPACT ON SOCIETY/ADDRESS TO SOCIAL ISSUES}

A Quality Function Deployment is recommended to determine the improvement of quality in service. In transport sector i.e. Bus services the customer continuously want more reliable, durable service in timely manner. In 


\section{International Journal of Innovations in Engineering and Science, www.ijies.net}

order to remain competitive all service sectors must become more responsive to customer and operate at world class level.

From general point of view the Voice of Customer (VoC) is defined as the identification, structuring and prioritization and customer need. This enables to fully understand and the customer expectations at the beginning of the research.

By studying literature review I have found that the authors have suggested on improvement the quality service must determine how the customer defines quality. The customer is typically surveyed to determine their expectations and these are than analyzed using Quality Function Deployment (QFD). Effective management of quality of system can lead to significant cost, reliability of customer and as well as increase comfort and also the low maintenance cost and extended service life.

A successful analysis of Quality Function Deployment (QFD) in various services is gathering the Voice of Customer to access how a service measures against what the customer expects.

\section{V- CONCLUSIONS}

Quality Function Deployment (QFD) it has been achieved remarkable popularity around the world in a wide variety of service or products. This is due to its systematic linking of customer requirements to and throughout the entire design, development and implementation the service. As customer requirements and technological advancements rapidly changes and it is necessary to assure that customer satisfaction is achieved in the quickest, least costly, and most deficient way possible. The important aspect of Quality Function Deployment (QFD) used in transport sector is a very effective means towards this end.

\section{REFERENCES}

[1] Ravi Kumar Singh, Virendra Rajput, Amit Sahay "A Literature Review on Quality Function Deployment (QFD)", Lasted Journal For Advanced Research In Applied Sciences Volume 5, Issue 8, August/2018.

[2] Dr. Chandu Ravi Kumar \& Dr. Ch. Venkata Krishna Reddy "A survey of passenger satisfaction on service quality of APSRTC", International Journal of Trend in Scientific Research and Development (IJTSRD) ISSN: 2456-6470, Volume - 2, Issue - 2, Jan-Feb 2018
[3] Sumit N. Balwani, "A Review paper on study and Applications of Quality Function Deployment in Quality improvement",International Conference on Recent Trends in Engineering Science and Technology (ICRTEST 2017) Volume: 5 Issue: 1(Special Issue 21-22 January 2017)

[4] K.Ch.A.Rao and Girish Thakar, "Enhancement of customer satisfaction of QFD in Bus Service", ISSN (Print): 2319 2526, Volume-2, Issue-5, 2013

[5] G. E. Barkavi, Dr. A.Mahadevan, Dr. R. Ramesh, "A Study on Quality Function Deployment of Public Bus Transport with special reference to Seats", Asian Journal of Research in Social Sciences and Humanities Vol. 6, No. 7, July 2016, pp. 1814-1821

[6] Michael D. Myers Kambiz Maani, "Use of quality function deployment in systems development: A case study”, Journal of International Information Management, Vol. 4 [1995], Issue. 1, Art. 5 